\title{
Grinding of swine mortality for compost under cold weather conditions for viral elimination
}

\author{
Brent Pepin ${ }^{1}$, Todd Williams ${ }^{2}$, Dale Polson ${ }^{3}$, Phillip Gauger $^{4}$, and Scott Dee ${ }^{2}$ \\ ${ }^{1}$ Pipestone Veterinary Services \\ ${ }^{2}$ Pipestone Veterinary Services \\ ${ }^{3}$ Boehringer Ingelheim Vetmedica Inc \\ ${ }^{4}$ Iowa State University
}

May 20, 2020

\begin{abstract}
The elimination of a foreign animal disease requires an efficient means of disposal for infected or exposed mortality and carcasses. Limited studies have been performed on the monitoring of swine viruses over time in compost piles, and this study looked to fill those knowledge gaps. The majority of the pig population in the United States resides in the Midwest, where adverse weather conditions in the winter exist. Therefore, this study aimed to evaluate the ability to grind carcasses for windrow formation to eliminate viral pathogens in the face of adverse weather conditions. This study further evaluated the environmental safety of the grinding processes and the potential for contamination from compost windrows themselves. The study reveals that grinding of infected carcasses in cold weather conditions is a low potential risk for environmental contamination of the air and groundwater. There is an observable difference between the compared compost materials used in virus elimination potential. The grinding and compost method is a viable option for carcass disposal in the face of a Foreign Animal Disease outbreak for pathogen elimination.
\end{abstract}

Grinding of swine mortality for compost under cold weather conditions for viral elimination

Short Running: Grinding swine mortality compost viral elimination

Brent Pepin ${ }^{1}$, Todd Williams ${ }^{1}$, Dale Polson ${ }^{2}$, Phil Gauger ${ }^{3}$, Scott Dee ${ }^{1}$

${ }^{1}$ Pipestone Veterinary Services, Pipestone, MN, USA

${ }^{2}$ Boehringer Ingelheim Animal Health, Duluth, GA, USA

${ }^{3}$ Iowa State University, Ames, IA, USA

\section{Corresponding author:}

Brent Pepin, DVM MS

1300 south Highway 75,

PO Box 188

Pipestone, MN 56164 USA

Email: brent.pepin@pipestone.com

Keywords (up to 6 keywords)

ASF, Compost, Grinding, Pre-processing, PED, PRRSV 


\section{Summary (up to 300 words)}

The elimination of a foreign animal disease requires an efficient means of disposal for infected or exposed mortality and carcasses. Limited studies have been performed on the monitoring of swine viruses over time in compost piles, and this study looked to fill those knowledge gaps. The majority of the pig population in the United States resides in the Midwest, where adverse weather conditions in the winter exist. Therefore, this study aimed to evaluate the ability to grind carcasses for windrow formation to eliminate viral pathogens in the face of adverse weather conditions. This study further evaluated the environmental safety of the grinding processes and the potential for contamination from compost windrows themselves. The study reveals that grinding of infected carcasses in cold weather conditions is a low potential risk for environmental contamination of the air and groundwater. There is an observable difference between the compared compost materials used in virus elimination potential. The grinding and compost method is a viable option for carcass disposal in the face of a Foreign Animal Disease outbreak for pathogen elimination.

\section{Introduction}

African Swine Fever Virus (ASF) is a highly contagious pathogen causing hemorrhages and higher fevers with mortality rates that approach 100\% (Ge et al., 2018). The recent fast spread of ASF across Russia, China, and Eastern Europe has heightened awareness of ASF and other World Health Organization reportable diseases as a threat to the United States (US) pork production (Dee et al., 2018; Guinat et al., 2016). An introduction in the US of Foot and Mouth Disease (FMD) or Classical Swine Fever (CSF) have a projected loss of $\$ 2.6-\$ 14$ billion (Dee et a., 2018; Paarlberg et al., 2009; Paarlberg et al., 2002). ASF introduction estimates to cause the US pork industry $\$ 15$ billion revenue loss in the first two years and up to $\$ 50$ billion over ten years (Carriquiry et al., 2020). Quick and effective methods for disease containment and elimination is a must to keep the financial burden of a new introduction of a Foreign Animal Disease (FAD) in the country to a minimum.

A diagnosis of a FAD like ASF in the US will evoke "stamping out policy" by which the goal is to eliminate an outbreak by the depopulation of all confirmed and exposed herds (World Organization for Animal Health, 2019). A successful depopulation to eradicate disease requires a means of disposing of infected carcasses in a manner that properly eliminates the virus to prevent further pathogen spread and exposure. FAD breaks in countries like the United Kingdom with FMD have shown the limitations of current carcass disposal methods (Wilkinson, 2007). An on-farm mass burial has legislative restrictions due to groundwater levels, burning presents public perception and human safety concerns, and the use of rendering facilities and landfills is troublesome due to the requirement of transporting infectious carcasses off-site (Scudamore et al., 2002; Wilkinson, 2007). Composting, however, is recognized as an environmentally friendly mortality management option for routine and emergency use in Australia, New Zealand, the US, and Canada (Guan et al., 2010; Wilkinson, 2007).

Studies on the degradation of swine viruses in compost material are limited, even for common industry viruses such as Porcine Reproductive and Respiratory Syndrome Virus (PRRSV) and Porcine Epidemic Diarrhea Virus (PEDV). Traditional composting of covering full carcasses in a carbon source is commonplace for regular daily mortality. However, the method of grinding of carcasses (pre-processing) with carbon sources before windrow formation may be better suited for mass depopulation. Pre-processing requires less land space to complete than traditional compost. Pre-processing also shows a faster completion in the composting process than full carcasses with cattle, but limited information is available for swine (Erickson et al., 2004). Many compost studies are also done in temperature-controlled containers or buildings and not in the outdoor setting that mass composting would likely occur (Guan et al., 2010; Vitosh-Sillman et al., 2017). The ability to compost outdoors and achieve the required high composting temperatures are of particular concern in cold weather situations that exist during winter in the Midwestern US, where the majority of the countries pork production exists (Oppedahl, 2020). The risk of environmental contamination and the spread of viruses is a concern for carcass disposal in FAD eradication events for which little information is available for swine viral pathogens. Thus the objectives of this study were to analyze environmental contamination risk of preprocessing of swine carcasses, ensure required temperatures to kill FAD swine pathogens in compost under 
cold weather conditions, and to monitor the ability of compost to denature common swine viruses.

\section{Materials and Methods}

Animals:

Animals in this study were used under the guidelines and approval of the Pipestone Research IACUC, protocol ID\# 2020-003. Five hundred sixty-six (566) feeder pigs were challenged with PRRSV and PEDV in a Biosecurity level 2 (BSL2) research facility by an oral transmission route in the feed. The concentration of challenge material for PRRSV and PEDV was 1x10^5 Median Tissue Culture Infectious Dose (TCID50) for both pathogens. All animals were humanely euthanized by penetrating captive bolt method, according to the American Veterinary Medical Association and the American Association of Swine Veterinarians guidelines. Pigs were confirmed exposed to the pathogens via oral fluid PCR testing and confirmed infected by serum and fecal swab PCR testing for PRRSV and PEDV, respectively. Forty (40) market hogs that were dead on arrival from a processing plant were also utilized for the grinding part of this study. The bioassay contained 30 pigs housed in a BSL2 research facility challenged with their respected samples, as described in the bioassay section of the material and methods.

Diagnostics:

All PRRSV and PEDV testing were completed by reverse transcription real-time polymerase chain reaction (PCR) testing at the Animal Disease Research and Diagnostic Laboratory at South Dakota State University according to standard diagnostic procedures. Compost grab samples were processed for testing, as described in a previous study where $10 \mathrm{~g}$ of the compost is combined with $25 \mathrm{ml}$ of minimal essential media (VitoshSillman et al., 2017). The sample was processed by stomacher blending for 2 minutes at $230 \mathrm{rpm}$. Supernatant media is separated for testing by PCR. Laboratory standard diagnostic procedures were used to test all compost, water, and air collection elution samples by oral fluid PCR diagnostic testing. Blood collection for serum occurred via jugular venipuncture with a single-use collection system. Samples were centrifuged at $1800 \mathrm{x} g$ for at least 10 minutes, after which serum was separated for testing. Fecal swabs were collected with individual sterile swabs (FisherFinest @ Transport Swab, Fisher Scientific, Pittsburgh, PA) by introduction into the pig's rectum.

Pre-processing (grinding):

All animal carcasses were pre-processed for compost by grinding using a $750 \mathrm{hp}$ horizontal grinder (Rotochopper@ FP-66 B-series, Rotochopper, INC, St. Martin, MN). Carcasses were placed with equal volumes of biomass during the grinding. The pig and biomass blended ground material was used for the windrow compost pile formation.

Compost biomass:

Three different carbon sources were used and compared: woodchips, cornstalk bales, and a 1:1 combination of the two. A separate windrow was formed for each of the three biomass types. Pig carcasses in each specific windrow biomass type were pre-processed with their respective carbon source.

Aerosol sampling:

Aerosol collection occurred with the use of six air collectors with 200 liters per minute flow rate at 60 minute run times (Innovaprep, Drexel, MO). Collectors were positioned downwind from the grinder and were operated during the entirety of the grinding procedure. Two air collectors were placed at each distance of $46 \mathrm{~m}$ (50 yards), $91 \mathrm{~m}$ (100 yards), and $137 \mathrm{~m}$ (150 yards) from the grinder. Samples for testing were collected at the end of the one-hour runtime by filter $0.075 \%$ Tween 20/PBS wet-foam elution kits (Innovaprep, Drexel, $\mathrm{MO})$.

Windrow formation:

Three windrows were formed, each representing one of the biomass compost material (woodchips, cornstalks, and a 1:1 combination of the two). A base layer of each biomass type was laid down before the application of 
the ground carcass material. The ground carcass material was then covered with the carbon material of each windrow's specific biomass type. Each windrow contained an end section composed of carcasses knowingly infected with PRRSV and PEDV (approximately 544kg of carcass weight per windrow). The rest of each windrow included a combination of remaining feeder pigs and the market weight hogs collected from the packing plant (approximately $3800 \mathrm{~kg}$ of feeder pigs and $1800 \mathrm{~kg}$ market hog carcass weight per windrow). Final windrow dimensions were three piles at $3.6 \mathrm{~m}$ wide, $10 \mathrm{~m}$ long, and $2.1 \mathrm{~m}$ high.

Water well and water collection:

In the locations shown in Figure 1, within each compost biomass type under the end section of knowingly infected surrogate pigs, three water wells were made at the depths of $0.15 \mathrm{~m}, 0.46 \mathrm{~m}$, and $0.91 \mathrm{~m}$ below ground surface. Three wells at the same depths were also placed $7.6 \mathrm{~m}$ downhill of the compost piles. Wells were drilled to their respective depths, and $0.15 \mathrm{~m}$ of slotted $0.102 \mathrm{~m}$ in width polyvinyl chloride (PVC) was placed at the bottom of each well. Sodium bentonite was placed around the top of the well where it extended from the ground. The slotted PVC was connected enough solid pipe to sit above the ground high enough to remain accessible after windrow formation was complete. All wells were capped to prevent water introduction from sources other than the ground in-between water collections. Water samples were collected by the use of a 3 -way catheter valve with enough rubber tubbing to reach the bottom of each well. A 60cc plastic syringe was then used to create the suction to collect the water from the respective well. The first water well collection attempt was made day five post windrow formation and continued once weekly until the completion of the study.

\section{Compost treatment:}

In the windrow section on the opposite end of the known PRRSV and PEDV positive feeder pig carcasses, a compost treatment to support microbial digestion was applied. As seen in Figure 1, each windrow had three sections. One end section with the known positive viral surrogate pigs and no compost treatment, one end section with a compost treatment for encouraging microbial digestion but no confirmed viral positive pigs, and a middle section of compost acted as a buffer area between the treated and untreated areas. In the treated segment of each windrow, three products were applied via a hand pump sprayer in equal volumes that are traditionally used to encourage liquid manure digestion. The application was over the processed carcass material before the top layer of biomass was added to complete the windrow. The products used were the digestive microbe blends Pit Accelerator (ProfitPro, LLC, Albert Lea, MN), and Microbial Manure Master (ProfitPro, LCC, Albert Lea, MN) and the liquid biocatalyst Eubio-NBS (Eubio Tec, Albert Lea, $\mathrm{MN})$.

Compost sample collection:

A sample was collected after the grinding was complete from each biomass type from the virus surrogate carcass section. Compost samples were initially collected daily for the first five days after windrow formation then weekly. PCR testing was performed on all compost samples for the presence of PRRSV and PEDV. Weekly compost sampling continued until two consecutive negative results were obtained from each windrow. At each collection point after windrow formation, two compost samples collected by a careful deconstruction of the biomass cover layer of the pile until the processed material was reached. At least a $10 \mathrm{~g}$ grab sample from the shallow outer layer of processed material and a sample from at least $0.91 \mathrm{~m}$ deep into the processed material was collected. Samples were collected wearing a shoulder-length plastic obstetrician sleeve, changing sleeve between each windrow type, and placing each $10 \mathrm{~g}$ sample into a sterile Whirl-Pak bag (Nasco, Fort Atkinson, WI, US) and stored at -80degC until testing.

Compost temperature and weather monitoring:

This study targeted a start in February in the upper Midwest when winter conditions in Minnesota average negative 11degC (-11degC) for the state to assess cold weather effects on the grind and compost method (https://arcgis.dnr.state.mn.us/ewr/climatetrends/\#). A local research weather monitoring station gathered the daily high and low temperatures during the study, along with the daily precipitation and snowfall 
(https://swroc.cfans.umn.edu/weather). Compost temperatures were monitored with $0.91 \mathrm{~m}$ long temperature probes placed at two locations in each pile, one in the area treated with products to encourage microbial digestion and one in the untreated compost area in the site of the known surrogate positive pigs. Compost temperatures readings were taken daily the first five days following windrow formation and then collected weekly to the completion of the study.

Environmental testing of for Swine DNA:

All air elution samples and all PCR negative PRRSV and PEDV compost samples from days 0-5 post windrow formation were tested for the presence of porcine (Sus scrofa) DNA (all viral positive compost samples saved for bioassay testing). In weeks 2 and 3, an additional compost sample from each windrow type was collected at the $0.91 \mathrm{~m}$ depth specifically for swine DNA testing. Testing was performed using a commercially available real-time PCR kit on the processed samples according to kit directions (RapidFinder Pork ID Kit, ThermoFisher Scientific, Waltham, MA, USA). Swine DNA testing was performed at the Iowa State University Veterinary Diagnostic Laboratory.

Bioassay:

The infectivity of PRRSV and PEDV PCR positive results of the compost samples were tested via swine bioassay. Thirty (30) pigs approximately three weeks in age and negative for PRRSV and PEDV were used. Pigs were housed in a BSL2 research facility and divided into ten pens with three pigs/pen. Pen design prevented any physical or manure contact between the pigs of different pens. Challenge material came from the PCR positive processed compost samples. On day 0, pigs were challenged with $2 \mathrm{ml}$ intramuscularly and $2 \mathrm{ml}$ orally with a specific PCR positive processed compost sample. Pigs were tested following exposure on day three and day seven post-challenge via individual serum and fecal swab for PRRSV and PEDV PCR, respectively. Pigs were also monitored for signs of diarrhea after challenge administration. After the bioassay, all pigs were humanely euthanized.

\section{Results}

Aerosol viral sampling:

The air collection occurred for 3 hours, beginning at the start of the grinding process. The grinding was completed at approximately 2.5 hours, but the aerosol collection at each distance ran for the full 3 hours. An aerosol sample was collected from each device after every 60min run time (18 total samples) for PCR testing. All filter elution samples tested negative for PRRSV and PEDV by PCR. Upon receiving negative virus results on all samples, filter pads from each collection point were vortexed with saline, and PCR retesting on the resulting fluid was attempted to increase testing sensitivity. All samples were PCR negative for PRRSV on the retest; however, a single PEDV PCR positive sample was detected in one collector at the $137 \mathrm{~m}$ (150 yards) distance with $36.55 \mathrm{ct}$ (cut-off used by the lab is $38 \mathrm{ct}$ ).

Water viral testing:

A water sample collection was attempted on every well weekly. Eleven total water well samples were able to be attained through the study, as seen in Table 1. The only positive PCR result was in week five on the $0.15 \mathrm{~m}$ well under the cornstalks biomass. Successful attempts to collect water samples were from depths of $0.15 \mathrm{~m}$ and $0.46 \mathrm{~m}$, with no samples collected from the $0.91 \mathrm{~m}$ depth.

Compost temperature by treatment and biomass type:

Regardless of compost sections microbial digestion treatment, the piles achieved similar temperature peaks, as reported in Table 2. By day three post windrow formation (pwf), each compost type reached an internal temperature of $60 \mathrm{deg} \mathrm{C}$ or higher and maintained that heat for at least 48 hours except for the treated section of the mixed biomass windrow that dropped to $55.6 \mathrm{degC}$ on day five pwf. Woodchips appeared to reach the highest peak compost temperature at $75.6 \mathrm{degC}$ on day three pwf. Woodchips and the treated section of the cornstalks reached temperatures $>60 \mathrm{deg} \mathrm{C}$ by day two pwf, a day before the mixed biomass. The average high air temperature for the first five days pwf when peak windrow temperatures were met was $3 \mathrm{degC}$ and 
the low was $-5.1 \operatorname{deg} C$. The only added moisture to the compost piles from the weather during the first five days pwf was minimal with $0.05 \mathrm{~cm}$ of rainfall and $0.51 \mathrm{~cm}$ of snowfall.

Compost viral testing:

Day 0 (when the carcass grinding and windrow formation occurred) revealed PCR positive results for both PEDV and PRRSV in all three biomass materials. As reported in Table 3, woodchips had a greater number of samples with PCR positive results for both PRRSV and PEDV compared to cornstalks and the combination material. Cornstalks compost provided the least amount of PRRSV and PEDV positive results. Table 3 shows that the last PRRSV positive result was detected on day four pwf in the woodchips, and PEDV was detected out to week 2 in both the woodchips and combination piles.

Swine DNA testing:

Swine DNA could be detected in the compost sample of each biomass type up to five days pwf. As seen in Table 4, at weeks 2 and 3 pwf, swine DNA could still be detected in each biomass type. Table 5 shows the results of the swine DNA detection from the air collection during the grinding process. Only two positive results were detected, occurring at hour 3 in one collector at the $46 \mathrm{~m}$ distance and one at the $91 \mathrm{~m}$ range. No swine DNA was detected at the $137 \mathrm{~m}$ distance.

Bioassay:

The PCR positive processed compost was placed into PRRSV and PEDV naive pigs to assess the infectivity of the virus detected. No PRRSV positive compost samples replicated to produce a PRRSV positive pig by serum PCR. Cornstalk biomass was negative for PEDV infection on bioassay. Woodchips provided the most PCR positive PEDV results by rectal swabs in the challenged pigs. As seen in Table 6, woodchip compost from day three and week two and the combination pile compost from week two produced a single PCR positive pig for PEDV on day four post-challenge, but all pigs were negative on day seven post-challenge. Clinical signs of diarrhea consistent with PEDV infection were observed in day 0,2 , and 4 pwf samples from the woodchips with multiple pigs in those pens testing positive by PCR. In the pen of pigs challenged with the week two combination biomass, one pig died from unrelated illness before the first sample collection.

\section{Discussion}

To the knowledge of the authors, the pre-processing (grinding) of infectious pig carcasses before composting has not been evaluated for potential environmental contamination. Although this study does not reduce any risk to zero, it does appear aerosolization of viral pathogens, and swine DNA is a low risk during the grinding process. The low risk is supported by Table 5, where no aerosolized swine DNA was detected at $137 \mathrm{~m}$, and by the only PCR viral positive being a relatively weak result attained only after the vortex of the filter itself. The air collectors were placed downwind from the grinder, giving the best situation for potential collection of virus and porcine nucleic acid. A limiting factor in this study was that we were only able to collect samples out to $137 \mathrm{~m}$ from the grinding process.

The carbon material that was placed underneath the carcass and carbon source ground material likely prevented significant leaching of viruses into the groundwater during this study. With ASF, previous studies have shown soil to be a poor fomite for viral survival, which may protect from groundwater leaching (MazurPanasuik \& Wozniakowski, 2020). In a study completed on an above-ground burial with Seneca Valley Virus positive pigs, carcasses were placed more intimately with the surrounding soil and leaching of the virus down to a depth of $46 \mathrm{~cm}$ but not $91 \mathrm{~cm}$ was found (B. Thaler, personal communication, April 22, 2020). In areas or times of more considerable rain or snowfall, the potential for leaching of pathogens into the soil and groundwater may be higher (Chatterjee et al., 2013; Grisey et al., 2010). Since this study was performed in the winter, the frozen soil under the windrows may have also prevented potential pathogen leaching. Further research is needed to assess the risk of pathogen aerosolizing from grinding and the potential leaching of swine viruses to the groundwater from contaminated carcasses.

This study was designed to assess the capability of using the grinding (pre-processing) of carcasses for 
composting in cold weather conditions to dispose of infected mortality and prevent pathogen transmission in the event of FAD break. While studies have shown that composting can eliminate swine diseases like FMD, PEDV, and PRRSV many of these studies were performed under very controlled and enclosed environmental conditions and not in exposed outdoor weather situations (Costa \& Akdeniz, 2019; Guan et al., 2010; VitoshSillman et al., 2017). In the pile sections treated with microbial stimulate, the most considerable numerical differences were seen in the mixed biomass windrow, but overall treated and untreated windrows sections were numerically similar. According to the US Environmental Protection Agency, pathogen reduction by time-temperature is classified as Class A or Class B, which is used to assess virus elimination capability (Costa \& Akdeniz, 2019). As seen in Table 2, all three biomass types in this study meet the qualification of Class A, which requires the composting temperature of $55 \mathrm{degC}$ for three consecutive days. Specifically pertaining to $\mathrm{ASF}$, maintaining $60 \mathrm{deg} \mathrm{C}$ for $15-20$ minutes is documented as adequate to eliminate the virus, which all compost types would have completed (Mazur-Panasuik et al., 2019; United States Department of Agriculture, 2018). Table 2 shows pre-processing compost was able to reach temperatures reported to eliminate pathogens even under the adverse cold weather conditions.

Although widely used around the world as a standard method for mortality disposal, there are limited peerreviewed reports on the survival of pathogens in composting swine mortality (Wilkinson, 2007). On the day of windrow formation, each biomass type was confirmed positive by PCR for the presence of PEDV and PRRSV nucleic acid. Outer and inner regions of the compost pile have the potential for differences in pathogen elimination, and previous literature supports the locations that were chosen for compost sampling in this study (Christensen et al., 2002; Wilkinson, 2007). In this study, direct compost sampling was targeted at a shallow outer location of the carcass/biomass blended material and a deeper depth (minimum $0.91 \mathrm{~m}$ into the carcass/biomass blended material). A previous study looking at PEDV detection in compost only collected samples after the $1^{\text {st }}$ and $2^{\text {nd }}$ temperature cycles were completed and did not perform a regular sample collection as conducted in the current study (Vitosh-Sillman et al., 2017). The present study and the literature demonstrate similar results where PEDV nucleic acid was not detected at the end of the first compost heat cycle (Vitosh-Sillman et al., 2017). ASF survival in different matrices was found to be dependent on the moisture content, with the most persistence in drier materials like straw and hay (MazurPanasuik \& Wozniakowski, 2020). A weakness of the current study is that the moisture content of the biomass material was not evaluated. However, woodchips used for compost can have a moisture content of $14.4 \%$ or lower, whereas cornstalks can have moisture content up to $76 \%$ (Ima \& Mann, 2007; Tannous, 2015; Xu et al., 2020). The lower moisture content of the woodchips may have contributed to the more extended detection of viral nucleic acid by PCR compared to windrows containing cornstalks. This theory is further supported by the increased infectious ability of PEDV seen in the woodchips on bioassay (Table 6 ). The results of this study suggest that cornstalks may be a better compost material than woodchips for the elimination of swine viruses.

The pathogens utilized in the current study are both RNA viruses. The higher stability of double-stranded DNA (as found in mammalian cells) is well known compared to RNA (Grosjean, 2009). The difference in RNA and DNA stability may explain the greater length of detection of swine DNA in the compost material compared to viral RNA. Also, the differences in the quantity of nucleic acid were likely higher in the swine carcasses compared to the magnitude of PRRSV and PEDV nucleic acid present from infection (Tables 3 and 4). To the knowledge of the authors, this is the first study looking at the detection of swine DNA in compost material over time. Detectable swine DNA decreased over time, as observed by the increasing negative results and the rising ct values attained in all windrow types. However, the expected length of time porcine DNA could be detected from composted carcasses remains unknown.

The use of bioassay to determine the infectious capability of a detected virus is a highly sensitive and conclusive method (Zimmerman et al., 2012). However, the use of bioassay to determine the infectious ability of compost material in swine has not been well documented. The results of the current study showed that PRRSV infectivity in compost material is short-lived regardless of the biomass used. However, PEDV nucleic acid detected in the compost material remained infectious in the woodchips out to four days after windrow formation but appeared non-infectious at time points afterward. The data in the current study 
suggests PEDV is not readily transmissible from windrows containing cornstalks showing a difference between composting materials. Although a single pig was positive by PEDV PCR in pens of week two woodchip and week two combination compost samples, no clinical signs of disease were observed. The positive pigs were also negative on repeat testing three days later, suggesting the PEDV detected at that time was not genuinely infectious.

This current study documents the potential ability for compost to eliminate domestic and foreign swine diseases successfully. However, it also pointed out the differences compost material can provide in disease elimination over time. Woodchips are commonly used as biomass for compost. However, this study shows that woodchips may not be as effective or as rapid at destroying viral nucleic acid compared to other material. In a mass depopulation event where multiple swine sites must dispose of large volumes of carcasses, the limitations of available carbon sources for compost is a concern. Having various options for compost disposal is needed for a rapid response to disease elimination efforts. The advantage of the method of grinding carcasses (pre-processing) is that less land space is required when compared to traditional full carcass composting. Grinding also allows for high temperatures to be reached very readily, and the current study shows that it may remove the need to turn the windrow and still be able to render pathogens non-viable. This study supports that the risk of environmental contamination from the grinding process is minimal, but requires further evaluation. Current research on the effect of compost, the compost biomass types used, and moisture content on pathogen survival in swine is limited and more research in this area is warranted.

\section{Data Availability Statement}

The data that support the findings of this study are available from the corresponding author upon reasonable request.

\section{Acknowledgments}

The authors would like to acknowledge the support of the National Pork Board, the Minnesota Board of Animal Health, Minnesota Pork Producers, and the Iowa Pork Producers Association for financial support in the completion of this study. Authors would also like to thank West Central Environmental Consultants (WCEC) and Double "D" Gravel, Inc. for their provision of and expertise of equipment necessary to complete this study.

\section{Conflict of Interest Statement}

The authors had no conflicts of interest in the completion and reported results of this study.

\section{Ethics Statement}

The authors confirm that the ethical policies of the journal have been followed. All procedures involving animals were in accordance with the Pipestone Research IACUC, protocol ID\#: 2020-003.

\section{References}

Carriquiry, M., Elobeid, A., Swenson, D., \& Hayes, D. (2020). Impacts of African Swine Fever in Iowa and the United States: Working paper 20-WP 600. Center for Agricultural and Rural Development, Iowa State University, Ames, IA USA.

Chatterjee, N., Flury, M., Hinman, C., \& Craig, G.C. (2013). Chemical and physical characteristics of compost leachates. A review. Department of Crop and Soil Sciences: Washington State University.

Christensen, K.K., Carlsbaek, M., \& Kron, E. (2002). Strategies for evaluating the sanitary quality of composting. Journal of Applied Microbiology, 92, 1143-1158. doi : 10.1046/j.1365-2672.2002.01648.x

Costa, T., \& Akdeniz, N. (2019). A review of the animal disease outbreaks and biosecure animal mortality composting systems. Waste management, 90, 121-131. doi: 10.1016/j.wasman.2019.04.047

Dee, S. A., Bauermann, F. V., Niederwerder, M. C., Singrey, A., Clement, T., de Lima, M., Long, C., Patterson, G., Sheahan, M. A., Stoian, A., Petrovan, V., Jones, C. K., De Jong, J., Ji, J., Spronk, G. D., 
Minion, L., Christopher-Hennings, J., Zimmerman, J. J., Rowland, R., Nelson, E., .. Diel, D. G. (2018). Survival of viral pathogens in animal feed ingredients under transboundary shipping models. PloS one, 13(3), e0194509. doi : 10.1371/journal.pone.0194509

Erickson, L.E., Fayet, E., Kakumanu, B.K., \& Davis, L.C. (2004).Anaerobic digestion. In: Carcass Disposal: A Comprehensive Review. Manhattan, KS: National Agricultural Biosecurity Center

Ge, S., Li, J., Fan, X., Liu, F., Li, L., Wang, Q., Ren, W., Bao, J., Liu, C., Wang, H., Liu, Y., Zhang, Y., Xu, T., Wu, X., \& Wang, Z. (2018). Molecular Characterization of African Swine Fever Virus, China, 2018. Emerging infectious diseases, 24(11), 2131-2133. doi : 10.3201/eid2411.181274

Grisey, E., Belle, E., Dat, J., Mudry, J., \& Aleya, L. (2010). Survival of pathogenic and indicator organisms in groundwater and landfill leachate through coupling bacterial enumeration with tracer tests. Desalination, 261(1-2), 162-168. doi : 10.1016/j.desal.2010.05.007

Grosjean, H. (2009). DNA and RNA modification enzymes structure, mechanism, function and evolution. United States: CRC Press.

Guan, J., Chan, M., Grenier, B.W., Spencer, J.L., Kranendonk, C., Copps, J., \& Clavijo, A. (2010). Degradation of foot-and-mouth disease virus during composting of infected pig carcasses. The Canadian Journal of Veterinary Research, 74, 40-44.PMID :20357957

Guinat, C., Gogin, A., Blome, S., Keil, G., Pollin, R., Pfeiffer, D. U., \& Dixon, L. (2016). Transmission routes of African swine fever virus to domestic pigs: current knowledge and future research directions. The Veterinary Record, 178(11), 262-267. doi : 10.1136/vr.103593

Hayes, D., Fabiosa J., Elobeid, A., \& Carriquiry, M. (2011). Economy wide impacts of a foreign animal disease in the United States: Working paper 11-WP 525. Center for Agricultural and Rural Development, Iowa State University, Ames, IA USA.

Ima, C. \& Mann, D. (2007). Physical properties of woodchip: Compost mixtures used as biofilter media. Agricultural Engineering International: the CIGR EJournal, Manuscript BC 07005.

Mazur-Panasiuk, N. \& Wozniakowski, G. (2020). Natural inactivation of African swine fever virus in tissues: Influence of temperature and environmental conditions on virus survival. Veterinary Microbiology, 242, 108609. doi:10.1016/j.vetmic.2020.108609

Mazur-Panasuik, N., Zmudzki, J., \& Wozniakowski, G. (2019). African swine fever - persistence in different environmental conditions and the possibility of its indirect transmission. Journal of Veterinary Research, 63, 303-310. doi: 10.2478/jvetres-2019-0058

Oppendahl, D.B. (2020). Improving Midwest agriculture and the environment. Chicago Fed Letter, Federal Reserve Bank of Chicago, issue 431. doi: 10.21033/cfl-2020-431

Paarlberg, P. L., Seitzinger, A. Hillberg, Lee, J. G., \& Mathews, K. H. Jr. (2009). Supply reductions, export restrictions, and expectations for hog returns in a potential classical swine fever outbreak in the United States. Journal of swine health and production, 17, 155-162

Paarlberg, P.L., Lee, J.G., \& Seitzinger, A.H. (2002). Potential revenue impact of an outbreak of foot and mouth disease in the United States. J Am Vet Med Assoc. 220, 988-992.doi :10.2460/javma.2002.220.988

Scudamore, J.M., Trevelyan, G.M., Tas, M.V., Varley, E.M, \& Hickman G.A. (2002). Carcass disposal: lessons from Great Britain following the foot and mouth disease outbreaks of 2001. Revue Scientifique et technique (International Office of Epizootics), 21(3), 775-787.doi : 10.20506/rst.21.3.1377

Tannous, K. (2015). Innovative solutions in fluid-particle systems and renewable energy management . Hershey, PA: Engineering Science Reference. 
United States Department of Agriculture. (2018). African Swine Standard Operating Procedure: Overview of Etiology and Ecology. Foreign Animal Disease Preparedness \& Response. https://www.aphis.usda.gov/animal_health/emergency_management/downloads/sop/sop_asf_e-e.pdf

Vitosh-Sillman, S., Loy D. J., Brodersen, B. Kelling, C., Eskridge, K., \& Schmidt, A. M. (2017). Effectiveness of composting as a biosecure disposal method of porcine epidemic diarrhea virus (PEDV)-infected pig carcasses. Porcine Health Management, 3, 22. doi : 10.1186/s40813-017-0068-z

Wilkinson, K.G. (2007). The biosecurity of on-farm mortality composting. Journal of Applied Microbiology, 102(3), 609-618. doi : 10.1111/j.1365-2672.2006.03274.x

World Organization for Animal Health. (2019). Terrestrial Animal Health Code (28 ${ }^{\text {th }}$ ed.). Paris, France.

Xu, Z., Li, G., Huda, N., Zhang, B., Wang, M., \& Luo, W. (2020). Effects of moisture and carbon/nitrogen ratio on gaseous emissions and maturity during direct composting of cornstalks used for filtration of anaerobically digested manure centrate. Bioresource Technology, 298, 122503. doi:10.1016/j.biortech.2019.122503

Zimmerman, J., Karriker, L.A., Ramirez, A., Schwartz, K.J., \& Stevenson, G.W. Diseases of Swine $\left(10^{\text {th }}\right.$ ed). Ames, IA: Wiley-Blackwell.

\section{Tables (each complete with title and footnotes)}

Table 1: Real-time PCR ct results for PRRSV and PEDV testing on water samples collected from wells placed below specific compost biomass types ${ }^{+}$and wells downhill at the designated depths

Week of collection after compost pile formation and virus tested

Week of collection after compost pile formation and viru

Week 1

PEDV

Week 2

PRRSV

Week 3

PEDV

PRRSV

Week 3

PEDV

PRRSV

Week 4

PEDV

PRRSV

Week 5

PEDV

Week 6

PRRSV

PEDV

PRRSV

${ }^{+}$Three biomass types used for windrow formation include woodchips, cornstalks, and a combination of half woodchips and half cornstalks

${ }^{++}$Wells placed $7.6 \mathrm{~m}$ downhill from the three compost windrows

$\S$ "-" signifies water collection was attempted but no sample present at that collection period

I "neg" signifies a negative PCR test result on the sample that collected for the well

Table 2: Weather conditions ${ }^{+}$and temperature readings of compost by biomass type ${ }^{++}$and treatment ${ }^{\mathrm{SS}}$ 


\begin{tabular}{|c|c|c|c|c|c|c|c|c|c|}
\hline $\begin{array}{l}\text { Time } \\
\text { post } \\
\text { windrow } \\
\text { formation }\end{array}$ & & & & & Woodch & sWoodch & sCornsta & SCornsta & sCombinati \\
\hline & $\begin{array}{l}\text { Total } \\
\text { Rainfall } \\
\text { (cm) }\end{array}$ & $\begin{array}{l}\text { Total } \\
\text { Snowfall } \\
(\mathrm{cm})\end{array}$ & $\begin{array}{l}\text { High } \\
\left({ }^{\circ} \mathbf{C}\right)\end{array}$ & $\begin{array}{l}\text { Low } \\
\left({ }^{\circ} \mathrm{C}\right)\end{array}$ & $\begin{array}{l}\text { Treated } \\
\left({ }^{\circ} \mathrm{C}\right)\end{array}$ & $\begin{array}{l}\text { Un- } \\
\text { treated } \\
\left({ }^{\circ} \mathrm{C}\right)\end{array}$ & $\begin{array}{l}\text { Treated } \\
\left({ }^{\circ} \mathrm{C}\right)\end{array}$ & $\begin{array}{l}\text { Un- } \\
\text { treated } \\
\left({ }^{\circ} \mathrm{C}\right)\end{array}$ & $\begin{array}{l}\text { Treated } \\
\left({ }^{\circ} \mathrm{C}\right)\end{array}$ \\
\hline Day 0 & 0.05 & 0.51 & -5.0 & -10.6 & 7.8 & 7.8 & 23.3 & 18.9 & 11.1 \\
\hline Day 1 & 0.00 & 0.00 & -1.1 & -6.7 & 15.6 & 15.6 & 26.7 & 46.1 & 12.2 \\
\hline Day 2 & 0.00 & 0.00 & 6.7 & -3.3 & $66.7^{\mathbb{I}}$ & 65.6 & 30.0 & 65.6 & 55.6 \\
\hline Day 3 & 0.00 & 0.00 & 7.2 & -3.3 & 75.6 & 74.4 & 63.3 & 67.8 & 68.9 \\
\hline Day 4 & 0.00 & 0.00 & 3.3 & -3.3 & 70.0 & 70.0 & 63.3 & 64.4 & 60.0 \\
\hline Day 5 & 0.00 & 0.00 & 6.7 & -3.3 & 73.9 & 72.2 & 62.2 & 62.2 & 55.6 \\
\hline $\begin{array}{l}\text { Week } \\
2\end{array}$ & 0.46 & 2.03 & 10.0 & -8.3 & 7.2 & 7.2 & 55.6 & 56.7 & 37.8 \\
\hline $\begin{array}{l}\text { Week } \\
3\end{array}$ & 1.52 & 0.76 & 6.7 & -11.1 & 37.8 & 10.0 & 27.8 & 14.4 & 11.1 \\
\hline $\begin{array}{l}\text { Week } \\
4\end{array}$ & 0.76 & 0.51 & 10.6 & -11.1 & 11.1 & 10.0 & 25.6 & 12.2 & 8.9 \\
\hline $\begin{array}{l}\text { Week } \\
5\end{array}$ & 5.66 & 0.76 & 15.6 & -6.7 & 32.2 & 28.9 & 18.9 & 34.4 & 15.6 \\
\hline
\end{tabular}

+For days 0-5, the total rainfall and snowfall recorded as the total for that day. For weeks 2-5 in the table, the rain and snow recorded as the total for the week. High and low temperatures are reported daily for days $0-5$, and the high and low temperatures are reported for the entire week for weeks 2-5

${ }^{++}$Three biomass types used for windrow formation include woodchips, cornstalks, and a combination of half woodchips and half cornstalks

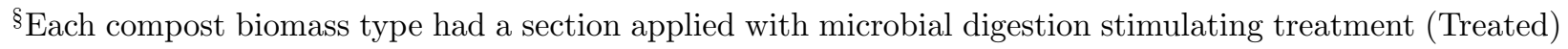
and a section that was not (Untreated)

I Bolded values indicated temperature readings [?]60degC which is documented high enough to inactivate ASF with 20minutes of exposure

Table 3: Real-time PCR ct results for PED and PRRSV testing of compost samples

\begin{tabular}{llll}
\hline Day post windrow formation and virus tested & Day post windrow formation and virus tested & & \\
\hline \multirow{2}{*}{ Day 0} & & Woodchips $^{+}$ & Woodchi \\
& PEDV & 29.60 & 29.60 \\
Day 1 & PRRSV & 29.07 & 29.07 \\
& & Deep $^{++}$ & Shallow \\
Day 2 & PEDV & 34.69 & $-\S$ \\
& PRRSV & 35.13 & - \\
Day 3 & PEDV & 34.2 & - \\
& PRRSV & 34.15 & - \\
Day 4 & PEDV & - & 35.59 \\
& PRRSV & - & - \\
Day 5 & PEDV & - & 34.32 \\
& PRRSV & - & 27.12
\end{tabular}




\begin{tabular}{llll}
\hline Day post windrow formation and virus tested & Day post windrow formation and virus tested & \\
\hline \multirow{2}{*}{ Week 2} & PRRSV & - & - \\
& PEDV & 37.05 & - \\
Week 3 & PRRSV & - & - \\
\multirow{2}{*}{ Week 4} & PEDV & - & - \\
& PRRSV & - & - \\
\hline
\end{tabular}

${ }^{+}$Three biomass types used for windrow formation include woodchips, cornstalks, and a combination of half woodchips and half cornstalks

${ }^{++}$Deep compost sample was at least $0.91 \mathrm{~m}$ into the carcass processed material of the compost. Shallow samples collected from the outer section of the processed carcass material directly under the carbon source covering of windrow

$\S$ "NS" denotes a sample collected on which PCR diagnostics could not be performed

I “_" represents a sample collected but for which PCR test results were negative

Table 4: Real-time PCR ct results for swine DNA testing in compost samples by biomass type ${ }^{+}$

\begin{tabular}{|c|c|c|c|c|c|c|}
\hline Time post windrow formation & Woodchips & Woodchips & Cornstalks & Cornstalks & Combination & Combinatic \\
\hline & Deep $^{++}$ & Shallow & Deep & Shallow & Deep & Shallow \\
\hline Day 1 & $\_\S$ & negI & - & - & 22.3 & 33.0 \\
\hline Day 2 & - & - & 21.9 & 13.5 & 21.4 & 21.8 \\
\hline Day 3 & 23.0 & - & 19.3 & 18.5 & 21.9 & 29.0 \\
\hline Day 4 & 20.5 & - & 13.5 & 19.1 & 24.2 & 27.1 \\
\hline Day 5 & 25.0 & 26.4 & 20.8 & 21.7 & 34.5 & 23.2 \\
\hline Week 2 & 23.7 & 23.7 & 19.4 & 19.4 & neg & neg \\
\hline Week 3 & 34.3 & 34.3 & neg & neg & 34.1 & 34.1 \\
\hline
\end{tabular}

+ Three biomass types used for windrow formation include woodchips, cornstalks, and a combination of half woodchips and half cornstalks

${ }^{++}$Deep compost sample was at least $0.91 \mathrm{~m}$ into the carcass processed material of the compost. Shallow samples collected from the outer section of the processed carcass material directly under the carbon source covering of windrow

$\S$ “-" denotes the swine DNA PCR was not performed on that sample

I "neg" signifies a negative PCR test result on the sample tested

Table 5: Real-time PCR ct results for swine DNA testing on air samples ${ }^{+}$during carcass pre-processing

\begin{tabular}{lll}
\hline Distance from grinder and hour of collection & Air Collector $\mathbf{1}$ & Air Collector 2 \\
\hline $46 \mathrm{~m} 1 \mathrm{hr}$ & Undetected $^{++}$ & Undetected \\
$46 \mathrm{~m} 2 \mathrm{hr}$ & Undetected & Undetected \\
$46 \mathrm{~m} 3 \mathrm{hr}$ & Undetected & 34.7 \\
& Air Collector $\mathbf{3}$ & Air Collector $\mathbf{4}$ \\
$91 \mathrm{~m} 1 \mathrm{hr}$ & Undetected & Undetected \\
$91 \mathrm{~m} 2 \mathrm{hr}$ & Undetected & Undetected
\end{tabular}




\begin{tabular}{lll}
\hline Distance from grinder and hour of collection & Air Collector $\mathbf{1}$ & Air Collector 2 \\
\hline $91 \mathrm{~m} 3 \mathrm{hr}$ & 33.6 & Undetected \\
& Air Collector $\mathbf{5}$ & Air Collector 6 \\
$137 \mathrm{~m} 1 \mathrm{hr}$ & Undetected & Undetected \\
$137 \mathrm{~m} 2 \mathrm{hr}$ & Undetected & Undetected \\
$137 \mathrm{~m} 3 \mathrm{hr}$ & Undetected & Undetected \\
\hline
\end{tabular}

${ }^{+}$Aerosol collectors were running with a 200 liters/minute flow rate at 1 hour run times for sampling. Six total collectors were used with two at each given distance from the grinder during the carcass pre-processing procedure

Table 6: Individual PCR results on fecal swabs of PEDV challenged bioassay pigs by biomass type and day post windrow formation

\begin{tabular}{|c|c|c|}
\hline Positive sample from day post windrow formation & Woodchips Biomass & Woodchips Biomas \\
\hline & Day 4 Post challenge & Day 7 Post Challeı \\
\hline Day 0 & $3 / 3$ & -++ \\
\hline Day 1 & $0 / 3$ & 0 \\
\hline Day 2 & $0 / 3$ & $2 / 3$ \\
\hline Day 3 & $1 / 3$ & $0 / 3$ \\
\hline Day 4 & $3 / 3$ & - \\
\hline Week 2 & $1 / 3$ & $0 / 3$ \\
\hline \multirow[t]{2}{*}{ Positive sample from day post windrow formation } & Cornstalks Biomass & Cornstalks Biom \\
\hline & Day 4 Post challenge & Day 7 Post Challeı \\
\hline Day 0 & $0 / 3$ & $0 / 3$ \\
\hline Day 1 & $0 / 3$ & $0 / 3$ \\
\hline \multirow[t]{2}{*}{ Positive sample from day post windrow formation } & $50 \%$ Woodchips / 50\% Cornstalks Biomass & $50 \%$ Woodchips \\
\hline & Day 4 Post challenge & Day 7 Post Challes \\
\hline Day 0 & $0 / 3$ & $0 / 3$ \\
\hline Week 2 & $1 / 2^{\S}$ & $0 / 2$ \\
\hline
\end{tabular}

${ }^{+}$Documents if pigs had clinical signs of scours consistent with PEDV infection

${ }^{++}$If all 3 piglets tested positive for PEDV and showed clinical signs they were removed from the study

$\S$ One pig died before the first sample collection

Figure Legends (figures and supporting information supplied in separate files)

Figure 1: Compost windrow and water well layout 


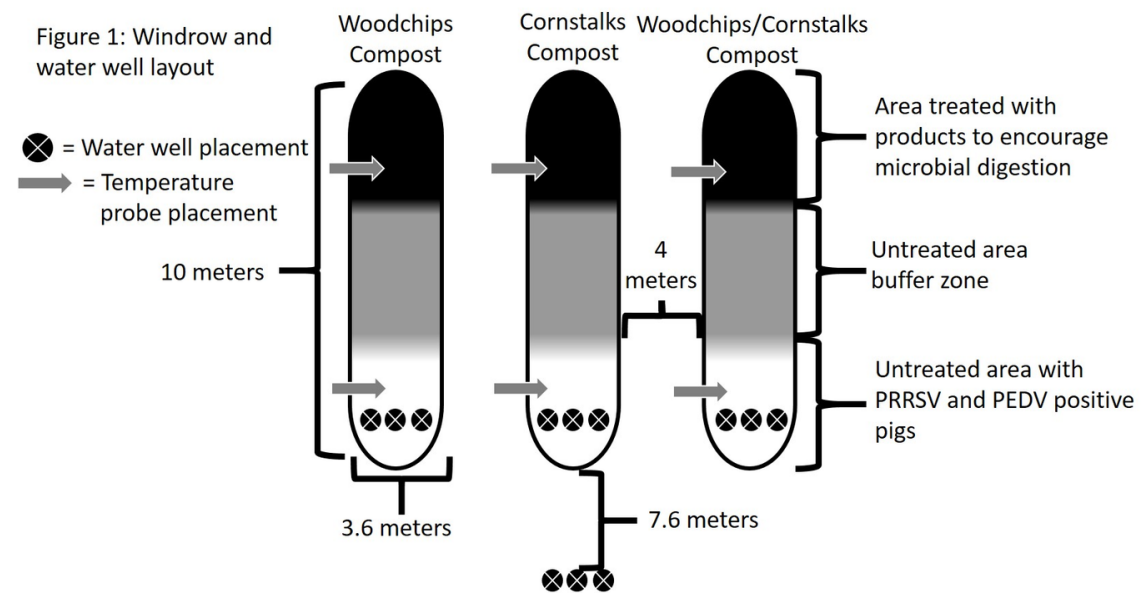

